ГОСПОДАРСЬКЕ ПРАВО ТА ПРОЦЕС

\author{
МОРГУНОВА Т. I., \\ кандидат технічних наук, доцент, \\ доцент кафедри професійних \\ та спеціальних дисциплін \\ (Херсонський факультет \\ Одеського державного університету \\ внутрішніх справ)
}

\title{
ЮРИДИЧНА ВІДПОВІДАЛЬНІСТЬ ЗА ЗЛОВЖИВАННЯ МОНОПОЛЬНИМ (ДОМІНУЮЧИМ) СТАНОВИЩЕМ НА РИНКУ
}

Стаття присвячена науковому дослідженню юридичної відповідальності за зловживання монопольним (домінуючим) становищем на ринку. У статті визначено види юридичної відповідальності за зловживання монопольним (домінуючим) становищем на товарному ринку та їх нормативне закріплення, а також проаналізовано підстави для застосування юридичної відповідальності за вказаний вид правопорушення. Розкрито поняття «зловживання монопольним (домінуючим) становищем на ринку». Досліджено нормативно-правові акти, які розкривають суть даного поняття та його ознаки. Визначено основну мету юридичної відповідальності за зловживання монопольним (домінуючим) становищем на ринку, а саме попередження недобросовісної конкуренції з боку суб'єктів господарювання. Розкрито підстави відповідальності за зловживання монопольним (домінуючим) становищем на ринку. Охарактеризовано об'єктивні і суб'єктивні ознаки даного правопорушення. Встановлено, що об'єктом даного правопорушення є суспільні відносини, які складаються у сфері економічних, господарських відносин і покликані забезпечувати свободу здійснення підприємницької діяльності в умовах добросовісної конкуренції на ринку. Визначено, що об’єктивна сторона правопорушення - це зовнішній прояв протиправного діяння, до ознак якого відносять його суспільно-небезпечний наслідок і причинний зв'язок. Встановлено, що суб'єкт даного правопорушення спеціальний, ним може бути тільки суб'єкт господарювання - монополіст на ринку. Досліджено суб'єктивну сторону правопорушення, яка характеризує ставлення суб'єкта правопорушення до вчинюваного ним діяння, у даному виді правопорушення форма вини (умисел чи необережність) не впливає на юридичну відповідальність. Встановлено, що мета юридичної відповідальності за зловживання монопольним (домінуючим) становищем на ринку полягає в попередженні таких негативних проявів у сфері господарювання, як недобросовісна конкуренція.

Виявлено основні причини зловживання монопольним (домінуючим) становищем на ринку та шляхи попередження такого негативного прояву.

Ключові слова: зловживання монопольним (домінуючим) становищем, юридична відповідальність, итраф, примусовий поділ, суб 'єкт господарювання, недобросовісна конкуренція.

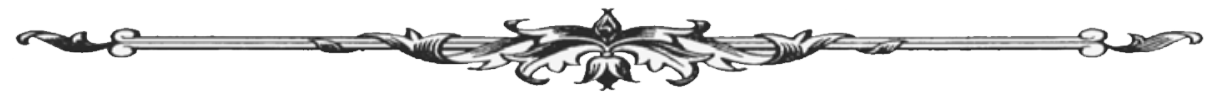


The article is devoted to the scientific study of legal responsibility for abuse of monopoly (dominant) position in the market. The article defines the types of legal responsibility for abuse of a monopoly (dominant) position in the commodity market and their normative fixing, and also analyzes the grounds for the use of legal responsibility for the specified type of offense. The concept of abuse of a monopoly (dominant) position in the market is revealed. The legal acts are revealed, which reveal the essence of this concept and its features. The main purpose of legal responsibility for the abuse of monopoly (dominant) position in the market, namely the prevention of unfair competition by economic entities, has been determined. The grounds for responsibility for abuse of monopoly (dominant) position in the market are revealed. The objective and subjective features of this offense are characterized. The object of this offense is public relations, which are formed in the sphere of economic, economic relations and are intended to ensure the freedom to engage in entrepreneurial activity in the conditions of fair competition in the market been established. The objective side of the offense is an outward manifestation of the unlawful act, to which it is attributable to the act, the socially dangerous consequence and the causal link been established. The subject of this offense is special, namely that it can only be an economic entity holding a monopoly position in the market been established. The subjective side of the offense is investigated, which characterizes the offender's attitude to the act he commits, and the form of guilt (intent or negligence) has no influence on legal liability for this type of offense been established. The purpose of legal responsibility for abuse of a monopoly (dominant) position in the market is to prevent such negative manifestations in the sphere of management as unfair competition been established.

The main causes of abuse of monopoly (dominant) position in the market and ways of prevention have been identified.

Key words: abuse of monopoly (dominant) position, legal responsibility, fine, forced division, business entity, unfair competition.

Вступ. Однією з умов розвитку ринкової економіки в Україні є формування належного конкурентного середовища. Досягнення цього передбачає подолання низки проблем організаційного і правового характеру. Із правового погляду законодавство, яке регулює діяльність суб'єктів господарювання, повинно бути спрямовано на встановлення, розвиток і забезпечення торгових та інших чесних звичаїв ведення конкуренції під час здійснення господарської діяльності в умовах ринкових відносин. До організаційних проблем належить високий рівень професіоналізму та чітке виконання функцій органами і посадовими особами, покликаними забезпечувати економічну конкуренцію. Тобто необхідною запорукою стабільного розвитку й функціонування вітчизняних товарних ринків є ефективна протидія негативним проявам монополізму. Серед сучасних видів порушень законодавства про захист економічної конкуренції суб' єктами господарювання досить поширене зловживання монопольним (домінуючим) становищем на ринку. Тому питання видів і підстав юридичної відповідальності за зловживання монопольним (домінуючим) становищем на ринку потребують додаткового дослідження.

Дослідженням проблем зловживання монопольним (домінуючим) становищем на ринку, зокрема аспектам юридичної відповідальності за такий вид правопорушення, були присвячені праці таких учених, як: 3. Борисенко, В. Грудницький, Г. Гук, Ю. Журик, В. Кулішенко, В. Лук’янець, С. Мельник, О. Стороженко, Т. Швидка, В. Щербина й ін.

Постановка завдання. Метою статті є визначення на основі аналізу чинного законодавства України видів юридичної відповідальності за зловживання монопольним (домінуючим) становищем на ринку та підстав її застосування.

Результати дослідження. Відповідно до ч. 1 ст. 13 Закону України «Про захист економічної конкуренції», зловживанням монопольним (домінуючим) становищем на ринку є дії

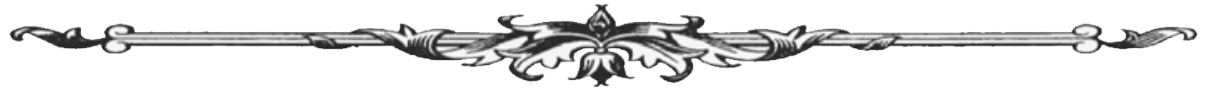


чи бездіяльність суб’єкта господарювання, який займає монопольне (домінуюче) становище на ринку, що призвели або можуть призвести до недопущення, усунення чи обмеження конкуренції, або ущемлення інтересів інших суб'єктів господарювання чи споживачів, які були б неможливими за умов існування значної конкуренції на ринку [1].

Законодавче визначення зумовлене і розвитком наукових досліджень провідними вченими. Так, на думку В. Грудницького, зловживання монопольним (домінуючим) становищем - це протиправна поведінка суб'єкта господарювання або групи суб'єктів господарювання, що займають монопольне (домінуюче) становище на ринку, шляхом використання ринкової влади, яка призводить або може призвести до недопущення, усунення чи обмеження конкуренції або ущемлення інтересів інших учасників ринкових відносин [2, с. 111].

У ч. 2 ст. 13 Закону України «Про захист економічної конкуренції» вказані види діянь, що становлять собою зловживання монопольним (домінуючим) становищем на ринку. Кожне з яких, відповідно до ч. 3 ст. 13 Закону України «Про захист економічної конкуренції», заборонясться і призводить до відповідальності згідно із законом [1].

На думку В. Грудницького, найпоширенішими видами зловживання монопольним (домінуючим) становищем на ринку є зловживання цінового характеру [3, с. 101].

Відповідно до ч. 2 ст. 13 Закону України «Про захист економічної конкуренції», видами цінових зловживань $є$ :

- встановлення таких цін чи інших умов придбання або реалізації товару, які неможливо було б встановити за умов існування значної конкуренції на ринку;

- застосування різних цін чи різних інших умов до рівнозначних угод із суб'єктами господарювання, продавцями чи покупцями без об'єктивно виправданих на те причин [1].

За такі види зловживань, як і за будь-які інші, може наставати господарська й адміністративна відповідальність. Конкретними санкціями можуть бути штраф та примусовий поділ відповідно. Доцільним буде зупинитись на кожному виді відповідальності окремо.

Що стосується господарсько-правової відповідальності за зловживання монопольним (домінуючим) становище на ринку, то вона регламентується Господарським кодексом України (далі - ГК України) [4] та Законом України «Про захист економічної конкуренції» (далі Закон). Ці два акти конкурентного законодавства мають низку спільних рис: вони обидва конкретизують зміст монополістичних зловживань (ст. 29 ГК України та ст. 13 Закону), містять перелік санкцій, які накладаються за ці зловживання (ст. ст. 40, 251, 253 ГК України та ст. ст. 51, 53 Закону); визначають суб'єктів, уповноважених розглядати відповідні господарські справи (ст. 257 ГК України та р. VII Закону); а також окреслюють загальні засади адміністративної відповідальності за зловживання монопольним (домінуючим) становищем посадових осіб і фізичних осіб-підприємців (ст. 252 ГК України та ст. 54 Закону) [5, с. 115].

Відповідно до ст. 52 Закону, за зловживання монопольним (домінуючим) становищем на ринку органи Антимонопольного комітету України накладають штрафи в розмірі до десяти відсотків доходу (виручки) суб'єкта господарювання від реалізації продукції (товарів, робіт, послуг) за останній звітний рік, що передував року, у якому накладається штраф. У разі наявності незаконно одержаного прибутку, який перевищує десять відсотків зазначеного доходу (виручки), штраф накладається в розмірі, що не перевищує потрійного розміру незаконно одержаного прибутку. Розмір незаконно одержаного прибутку може бути обчислено оціночним шляхом [1].

Коли доходу (виручки) немає або відповідач на вимогу органів Антимонопольного комітету України, голови його територіального відділення не надав інформації про розмір доходу (виручки), штраф накладається в розмірі до двадцяти тисяч неоподатковуваних мінімумів доходів громадян. Відповідно до ст. 53 Закону, якщо суб'єкт господарювання зловживає монопольним (домінуючим) становищем на ринку, органи Антимонопольного комітету України мають право ухвалити рішення про примусовий поділ суб'єкта господарювання, що займає монопольне (домінуюче) становище [1].

Крім того, зрозумілим $є$ той факт, що таке порушення, як зловживання монопольним (домінуючим) становищем на ринку, може завдати значної шкоди суб'єктам

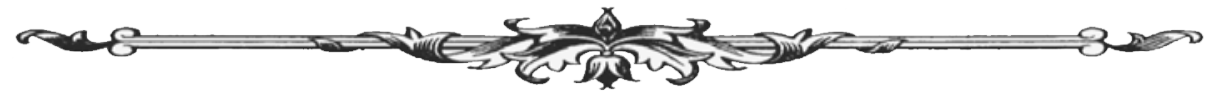


господарювання, і тому шкода, завдана порушеннями законодавства про захист економічної конкуренції у вигляді зловживання монопольним становищем, компенсується особою, що вчинила порушення, у подвійному розмірі завданої шкоди [1].

Відповідно до ст. 255 ГК України, збитки, завдані зловживанням монопольним (домінуючим) становищем, антиконкурентними узгодженими діями, дискримінацією суб'єктів господарювання органами державної влади, органами місцевого самоврядування, а також збитки, завдані внаслідок вчинення дій, визначених ГК України як недобросовісна конкуренція, підлягають відшкодуванню за позовами заінтересованих осіб у порядку, встановленому законом. Відшкодування збитків здійснюється в судовому порядку, але тільки за ініціативою суб’ єкта господарювання, який зазнав їх від такого порушення [4].

Стосовно адміністративної відповідальності за зловживання монопольним (домінуючим) становищем, відповідно до ст. 166-1 Кодексу України про адміністративні правопорушення, за зловживання монопольним становищем на ринку передбачено накладення штрафу на керівників (розпорядників кредитів) підприємств (об'єднань, господарських товариств тощо) у розмірі до п’ятнадцяти неоподатковуваних мінімумів доходів громадян, а на осіб, які займаються підприємницькою діяльністю, - до тридцяти неоподатковуваних мінімумів доходів громадян [6]. Відповідно до п. 3 ч. 1 ст. 16 Закону України «Про Антимонопольний комітет України», державний уповноважений Антимонопольного комітету України має повноваження складати протоколи, розглядати справи про адміністративні правопорушення, виносити постанови в цих справах [7].

Тобто Антимонопольний комітет України має право за порушення законодавства у формі зловживання монопольним (домінуючим) становищем на ринку застосовувати стягнення, які передбачені Законом України «Про захист економічної конкуренції», i ті, що передбачені Кодексом України про адміністративні правопорушення (далі - КУпАП).

На нашу думку, найбільше значення для притягнення до юридичної відповідальності за зловживанням монопольним (домінуючим) становищем має достатність підстав для застосовування уповноваженими суб'єктами господарсько-правової чи адміністративної відповідальності.

За загальним правилом підставою для юридичної відповідальності за зловживання монопольним становищем на ринку є наявність у діях суб'єкта складу правопорушення, передбаченого Законом, ГК України та КУпАП, що включає такі елементи: об'єкт правопорушення, об'єктивну сторону правопорушення, суб'єкт правопорушення і суб'єктивну сторону правопорушення. Зупинимося на кожному елементі окремо.

Об’єктом даного правопорушення є суспільні відносини, які складаються у сфері економічних, господарських відносин і покликані забезпечувати свободу здійснення підприємницької діяльності в умовах добросовісної конкуренції на ринку.

Об'єктивна сторона правопорушення - це зовнішній прояв протиправного діяння, до ознак якого його відносять діяння, суспільно небезпечний наслідок і причинний зв'язок. Але незалежно від настання наслідку зловживання монопольним (домінуючим) становищем на ринку небезпечне для економіки. 3 об' єктивної сторони необхідним є те, щоб діяння підпадало під ознаки такого, що передбачено в Законі, ГК України і ст. 166-1 КУпАП.

Суб'єкт даного правопорушення спеціальний, а саме ним може бути тільки суб'єкт господарювання, що займає монопольне становище на ринку. І в цьому аспекті слід погодитися 3 Т. Швидкою, що для притягнення суб'єкта господарювання за зловживання монопольним становищем необхідно довести факт займання цим суб'єктом монопольного (домінуючого) положення. Процес визначення монопольного становища передбачає здійснення поетапної спеціальної процедури, після проведення якої робиться висновок про наявність чи відсутність монопольного (домінуючого) становища підприємства на ринку [8, с. 3]. Даний процес визначений у спеціальному нормативно-правовому акті - Методиці визначення монопольного (домінуючого) становища суб’ єктів господарювання на ринку від 5 березня 2002 р. № 49-р [9].

Законом визначено поняття «монопольне становище суб'єкта господарювання» як таке, що дозволяє йому визначати умови обороту товарів на ринку. Це може бути одиничний

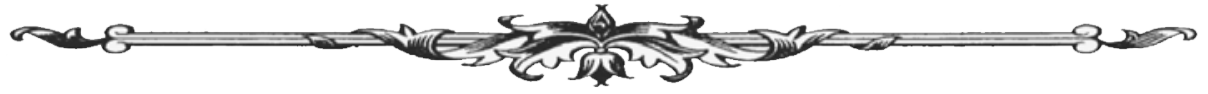


або груповий суб'єкт, але обов'язковою ознакою є відсутність у нього конкурентів на ринку, або він не повинен зазнавати значної конкуренції внаслідок обмеженого доступу інших суб'єктів на ринок, тобто внаслідок певних бар'єрів, створених даним суб'єктом господарювання [8, с. 4]. Законом передбачено відсоткові долі суб'єкта господарювання на ринку для одиничного суб'єкта - 35\% і більше, для двох-трьох суб'єктів господарювання $-50 \%$ і більше, для трьох-чотирьох $-70 \%$ і більше [1].

Стосовно суб'єктивної сторони правопорушення, вона характеризує ставлення суб'єкта правопорушення до вчинюваного ним діяння і в даному виді правопорушення можна говорити, що форма вини (умисел чи необережність) не мають впливу на юридичну відповідальність. Але, на нашу думку, здебільшого вони характеризуються умисною формою. Такого висновку ми доходимо в результаті проведеного аналізу видів зловживання монопольним (домінуючим) становищем на ринку.

Стосовно притягнення до відповідальності за зловживанням монопольним (домінуючим) становищем варто звернутися до теорії адміністративного права, де визначено, що для притягнення до адміністративної відповідальності слід встановити наявність трьох підстав:

- фактичної;

- юридичної;

- процесуальної.

До фактичної підстави належить сам факт учинення діянь, які за своїми ознаками підпадають під зловживанням монопольним (домінуючим) становищем.

До юридичних підстав належить наявність відповідних норм права, які встановлюють види зловживанням монопольним (домінуючим) становищем і види відповідальності за такі дії.

До процесуальних підстав належить порядок притягнення до відповідальності, який передбачає складання відповідного протоколу уповноваженою особою про вчинене правопорушення й ухвалення відповідного рішення про застосування санкції. Формою такого рішення може бути постанова про накладення адміністративного стягнення чи рішення про застосування господарсько-правових санкцій.

Що стосується причин зловживанням монопольним (домінуючим) становищем, то варто погодитись із В. Грудницьким, що ними є:

- вади нормативно-правових актів, які регулюють сфери народного господарства;

- низький рівень конкуренції на загальнодержавному та регіональному рівнях;

- низький рівень конкурентної культури;

- високий рівень монополізації деяких товарних ринків;

- необгрунтоване віддання переваги органами державної влади певним суб'єктам господарювання;

- неналежне врегулювання допомоги з боку держави суб'єктам господарювання тощо $[10$, c. 81$]$.

Для подолання зловживання монопольним становищем у нашій країні важливою $\epsilon$ можливість звернення до органів Антимонопольного комітету України за роз'ясненням щодо відповідності дій суб'єктів господарювання нормам антимонопольно-конкурентного законодавства. Антимонопольний комітет повинен передусім сприяти захисту прав споживачів і суб'єктів господарювання, державних та суспільних інтересів. Усі ці дії спрямовані на підтримку національного товаровиробника, створення належних умов для його розвитку та виходу на міжнародний рівень [11, с. 858].

Одним зі шляхів подолання зловживань монопольним (домінуючим) становищем на ринку. на думку В. Лук'янець, $є$ те, що Україна повинна адаптувати національне законодавство до законодавста країн Європейського Союзу [12 с. 171]. Але зрозуміло, що це довготривалий і витратний аспект, якого ми намагаємось досягти.

Висновки. Отже, зловживанням монопольним (домінуючим) становищем на ринку можна визначити як дії чи бездіяльність суб'єкта господарювання, який займає монопольне (домінуюче) становище на ринку, що призвели або можуть призвести до недопущення, усунення чи обмеження конкуренції.

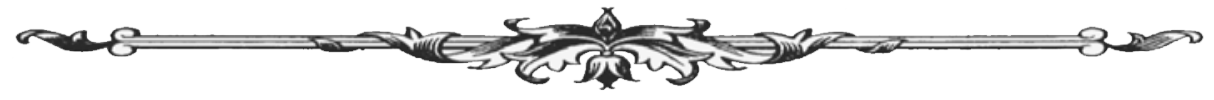


За вчинення правопорушення у формі зловживання монопольним (домінуючим) становищем у законодавстві передбачено застосування юридичної відповідальності двох видів: господарсько-правової й адміністративної, що можуть застосовуватись у вигляді штрафу та примусового поділу.

Підставою для юридичної відповідальності за зловживання монопольним становищем на ринку є склад цього правопорушення, проте для кваліфікації дій суб'єктів господарювання як зловживання монопольним (домінуючим) становищем на ринку достатнім $\epsilon$ встановлення самого факту вчинення дій, визначених законом як зловживання монопольним (домінуючим) становищем. Для більшої обгрунтованості застосування юридичної відповідальності варто встановити фактичну, юридичну і процесуальні підстави.

Мета юридичної відповідальності за зловживання монопольним (домінуючим) становищем на ринку полягає в попередженні таких негативних проявів у сфері господарювання, як недобросовісна конкуренція. Усе це зумовлює подальше вивчення і дослідження інституту юридичної відповідальності в господарському праві.

\section{Список використаних джерел:}

1. Про захист економічної конкуренції : Закон України від 11 січня 2001 р. № 2210-III. Відомості Верховної Ради Украӥни. 2001. № 12.

2. Грудницький В. Удосконалення законодавства щодо поняття та видів зловживання монопольним (домінуючим) становищем. Форум права. 2014. № 4. С. 107-112. URL: http://nbuv.gov.ua/UJRN/FP_index.

3. Грудницький В. Характеристика видів зловживання монопольним (домінуючим) становищем. Право і суспільство. 2016. № 1. С. 100-105. URL: http://nbuv.gov.ua/UJRN/ Pis_2016_1_19.

4. Господарський кодекс України від 16 січня 2003 р. № 436-IV. Відомості Верховної Ради України. 2003. № 18. Ст. 144.

5. Горбатюк Я. Види та підстави юридичної відповідальності за зловживання монопольним (домінуючим) становищем на товарному ринку. Юридичний вісник. Повітряне і космічне право. 2017. № 3. C. 114-119. URL: http://nbuv.gov.ua/UJRN/Npnau_2017_3_20.

6. Кодекс України про адміністративні правопорушення від 7 грудня 1984 р. № 8073-Х. Відомості Верховної Ради Української Радянської Соиіалістичної Республіки. 1984. № 51. Ст. 1122.

7. Про Антимонопольний комітет України : Закон України від 26 листопада 1993 р. № 3659-XII. Відомості Верховної Ради України. 1993. № 50. Ст. 472.

8. Швидка Т. Кваліфікація монопольного становища на ринках та підстави притягнення до відповідальності за зловживання ним. Теорія $і$ практика правознавства. 2018. Вип. 2. URL: http://nbuv.gov.ua/UJRN/tipp_2018_2_11.

9. Методика визначення монопольного (домінуючого) становища суб'єктів господарювання, затв. розпорядженням Антимонопольного комітету України від 5 березня 2002 р. № 49-р. Офіційний вісник Украӥни. 2002. № 14.

10.Грудницький В. Припинення зловживання монопольним (домінуючим) становищем. Актуальні проблеми вітчизняної юриспруденції. 2017. Вип. 1 (2). С. 78-81. URL: http://nbuv.gov.ua/UJRN/apvu_2017_1(2)_20.

11.Гук Г. Зловживання монопольним (домінуючим) положенням в антимонопольному законодавстві європейського співтовариства та України. Молодий вчений. 2017. № 11. C. 856-859. URL: http://nbuv.gov.ua/UJRN/molv_2017_11_209.

12. Лук'янець В., Травнікова К. Зловживання домінуючим становищем за антимонопольним правом України та конкурентним правом СС: порівняльний аспект. Науковий вісник Ужггородського національного університету. Серія «Право». 2017. Вип. 43 (1). С. 169-171. URL: http://nbuv.gov.ua/UJRN/nvuzhpr_2017_43(1)_44.

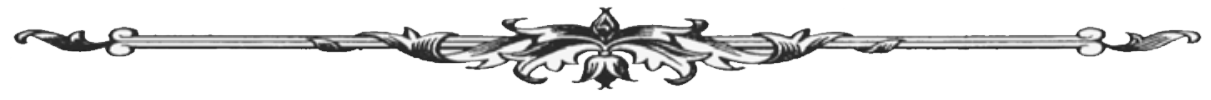

